\title{
Identifikasi Produktivitas Pekarangan Berdasarkan Periode Panen Untuk Menunjang Ketahanan Pangan Rumah Tangga di Kecamatan Sangatta Utara
}

\author{
Bahar ${ }^{1}$, Taufan Purwokusumaning Daru², Hadi Pranoto ${ }^{3}$, Surya Darma ${ }^{4}$, \\ dan Suria Darma Idris ${ }^{5}$ \\ 1,2,3,4,5 Program Studi Magister Pertanian Tropika Basah, Universitas Mulawarman \\ Jl. Krayan Kampus Gunung Kelua, Samarinda \\ 1Email : bahar78sangatta@gmail.com
}

\begin{abstract}
Food security has become a major challenge in various countries including Indonesia. Food security problem was a local, national and global problem that continues to be sought for a solution. Research aims to identify the composition and utilization pattern of community, crop production from home garden in one-month period, productivity and potential homegarden utilization to support family food security in District of North Sangatta, East Kutai Regency. Research was conducted on April-May 2019 in East Kutai Regency, District of North Sangatta. The research were used was a survey method. Samples were taken from farm households as many as 30 samples intentionally (purposive sampling) with home garden area grouped into three strata, namely strata 1 (0.5-1.0 ha), strata 2 (>1-1.5 ha) and strata 3 (>1.5-2.0 ha). Obtained data were analyzed descriptively (quantified) by Analysis of Data Regression by Excel Office 2010. Utilization of home garden in the District of North Sangatta provides a significant contribution in improving the household economy and supporting family food security. The production levels showed income from household home garden was high, with an average income above $75 \mathrm{~kg}$ rice month ${ }^{-1}$.
\end{abstract}

Keywords: Food Security, Composition, Home Garden, Productivity, Household

\begin{abstract}
ABSTRAK
Ketahanan pangan telah menjadi tantangan utama berbagai negara termasuk Indonesia. Permasalahan ketahanan pangan merupakan permasalahan lokal, nasional, dan global yang terus dicari solusinya. Tujuan penelitian adalah untuk mengidentifikasi komposisi, pola pemanfaatan, produksi, produktivitas dan potensi pemanfaatan lahan pekarangan masyarakat untuk mendukung ketahanan pangan keluarga di Kecamatan Sangatta Utara Kabupaten Kutai Timur. Penelitian ini dilaksanakan pada bulan April-Mei 2019 di Kabupaten Kutai Timur Kecamatan Sangatta Utara. Metode yang digunakan adalah metode survei. Sampel berasal dari rumah tangga petani sebanyak 30 sampel secara sengaja (purposive sampling) dengan luas lahan pekarangan yang dikelompokan menjadi tiga strata yaitu strata 1 $(0,5-1.0 \mathrm{ha})$, strata $2(>1-1,5 \mathrm{ha})$ dan strata $3(>1,5-2,0 \mathrm{ha})$. Data yang diperoleh dianalisis secara deskriptif (dikuantitatifkan) dengan Analysis of Data Regression by Excel Office 2010. Pemanfaatan lahan pekarangan di Kecamatan Sangatta Utara memberikan kontribusi cukup besar dalam peningkatan ekonomi rumah tangga dan menunjang ketahanan pangan keluarga. Tingkat produksi menunjukkan pendapatan dari lahan pekarangan rumah tangga tinggi, dengan rata-rata pendapatan diatas 75 $\mathrm{kg}$ beras bulan-1.

Kata kunci: Ketahanan Pangan, Komposisi, Pekarangan, Produktivitas, Rumah Tangga
\end{abstract}




\section{Pendahuluan}

Ketahanan pangan telah menjadi tantangan utama berbagai negara termasuk Indonesia. Permasalahan ketahanan pangan adalah permasalahan lokal, nasional maupun global yang memerlukan solusi untuk mengatasinya. Kebutuhan akan pangan dalam konteks lokal terasa menguat dan mendesak. Persoalan ketahanan pangan secara teknis berbanding lurus dengan ketersediaan lahan usaha pertanian. Permasalahan ini muncul dikarenakan laju pertumbuhan penduduk, penurunan luas area pertanian, kondisi iklim yang ekstrim dan kualitas lahan sehingga menimbulkan kerawanan pangan.

Jika suatu rumah tangga dimana seluruh anggota rumah tangga tidak dihantui oleh ancaman kelaparan, dapat dikatakan rumah tangga tersebut memiliki ketahanan pangan (FAO, 2006) dimana ketahanan pangan adalah suatu konsdisi yang berkaitan dengan tersedianya bahan pangan secara terus menerus atau berkelanjutan. Pangan (food) merupakan kebutuhan dasar manusia yang terpenting disamping papan, sandang, pendidikan, kesehatan. Pengertian pangan menurut UU RI Nomor 18 Tahun 2012 tentang pangan adalah segala sesuatu yang berasal dari sumber hayati produk pertanian, perkebunan, kehutanan, perikanan, peternakan, perairan, dan air, baik yang diolah maupun tidak diolah yang diperuntukkan sebagai makanan atau minuman bagi konsumsi manusia, termasuk bahan tambahan pangan, bahan baku pangan, dan bahan lainnya yang digunakan dalam proses penyiapan, pengolahan, dan/atau pembuatan makanan atau minuman.

World Summit of Food Security (WSFS) tahun 2009, definisi konsep dan spesifikasi ketahanan pangan diperluas menjadi empat pilar, yaitu ketersediaan pangan, akses pangan, pemanfaatan pangan, dan stabilitas pangan serta menyatakan bahwa dimensi gizi integral terhadap konsep tersebut (FAO, 2009). Ketersediaan pangan yaitu tersedianya pangan yang cukup melalui produksi sendiri atau cara lain yang ada berkelanjutan misalnya dalam kasus suatu negara yang tidak mempunyai lahan subur atau sumber daya untuk penanaman tanaman pangan (Fawole dan Ozkan, 2017). Definisi akses pangan (food access) menurut Cholida (2016) yaitu jika kuantitas maupun kualitas pangan mampu diperoleh dan untuk memenuhi kebutuhan gizi seluruh anggota keluarga.

Fawole dan Ozkan (2017) pemanfaatan pangan (food utilization) berarti memastikan hasil gizi yang baik yang dapat disebut keamanan gizi yaitu ada kebersihan pribadi yang cukup untuk penyerapan nutrisi yang ada dalam pangan. Pemanfaatan pangan mencakup faktor-faktor lain seperti kebersihan pribadi dan sanitasi air. Leroy et al (2015) berpendapat stabilitas pangan (stability of food) adalah dimensi lintas sektoral yang mengacu pada makanan yang tersedia dan dapat diakses dan pemanfaatannya memadai setiap saat, sehingga orang tidak perlu khawatir tentang risiko menjadi tidak aman pangan selama musim tertentu atau karena peristiwa eksternal. 
Kabupaten Kutai Timur salah satu dari 71 Kabupaten yang Indeks Ketahanan Pangan (IKP) masuk dalam kelompok rentan pangan yaitu kelompok 1-3 berdasarkan cut off point IKP dengan skor IKP 57,58, hal ini diindikasikan oleh: 1) tingginya rasio konsumsi per kapita terhadap produksi bersih per kapita, 2) tingginya prevalensi balita stunting, dan 3 ) tingginya penduduk miskin. Kabupaten yang berada di daerah rentan pangan kelompok 1-3 rata-rata konsumsi terhadap produksi pangan sebesar 4,27 , hal ini dikarenakan untuk memenuhi kebutuhan pangan penduduk dari kebupaten-kabupaten tersebut sangat tergantung suplai pangan dari wilayah lain yang merupakan daerah sentra pangan (BKP Kementan, 2019).

Menurut BKP Kabupaten Kutai Timur (2017) bahwa Pemerintah Kabupaten Kutai Timur secara umum mampu menyediakan dan mendistribusikan pangan secara merata keseluruh daerah, namun belum menjadi jaminan untuk memenuhi jumlah kebutuhan pangan tercukupi, bermutu, bergizi, berimbang dan aman untuk seluruh penduduk Kutai Timur. Hal ini dikarenakan masih terdapat sebagian masyarakat yang tinggal di daerah rawan pangan yang belum mampu mengakses pangan. Kecamatan di Kutai Timur masih ada sebanyak $61,11 \%$ masuk dalam kategori rawan pangan sampai cukup rawan pangan, baik yang bersifat kronis dan transien berdasarkan hasil analisis Sistem Kewaspadaan Pangan dan Gizi (SKPG) dan skor Pola Pangan Harapan (PPH) baru mencapai 73,9 point, hal ini menandakan pola komsumsi pangan masyarakat masih jauh dari harapan.

Pencapaian ketahanan pangan dan kedaulatan pangan Kabupaten Kutai Timur terancam akibat alih fungsi lahan pertanian. Kemiskinan dan terbatasnya infrastruktur pedesaan menjadikan Kutai Timur berpotensi mengalami kerawanan pangan yang relatif tinggi. Keterbatasan sarana dan prasarana sebagai penunjang pelayanan di bidang ketahanan pangan merupakan alasan tidak lancarnya dan ketidakjelasannya proses pendistribusian pangan, baik pemanfaatan teknologi dan informasi di bidang ketahanan pangan belum optimal. Kebijakan ketahanan pangan nasional, provinsi dan kabupaten/kota belm terintegrasi. Dewan Ketahanan Pangan (DKP) sebagai wadah Koordinasi Organisasi Perangkat Daerah (OPD) belum optimal dalam penyelenggaraan ketahanan pangan. Sumberdaya manusia masih kurang dalam penanganan di bidang penganekaragaman pangan, ketersediaan pangan, distribusi pangan dan komsumsi sehingga ketersediaan pangan antar waktu dan wilayah tidak merata (BKP Kabupaten Kutai Timur, 2017).

Permasalahan pemenuhan ketahanan pangan terkendala akibat dari alih fungsi lahan pertanian untuk penggunaan non pertanian mengakibatkan terjadinya kompetisi dalam pemanfaatan lahan yang akan menghambat terjadinya peningkatan kapasitas produksi pangan dikarenakan luas lahan pertanian semakin sempit, sehingga semakin menambah daftar permasalahan beban ketahanan pangan. Permasalahan tersebut dapat diatasi dengan memanfaatkan segala sumber daya lahan yang tersedia termasuk lahan 
pekarangan secara benar dan terencana. Ketahanan pangan keluarga bisa diwujudkan melalui pemanfaatan lahan pekarangan yang dikelola secara optimal. Menurut Nurwati et al (2015) bahwa lahan pekarangan yang dimanfaatkan secara optimal akan mampu mendukung ketersediaan pangan dan membantu pemenuhan kebutuhan pangan rumah tangga.

Pekarangan adalah tanah yang berada disekitar rumah baik terletak di depan, samping, belakang bangunan, tergantung seberapa luas sisa tanah yang tersisa setelah digunakan untuk membuat rumah atau bangunan utama dan mempunyai batas kepemilikan yang jelas (Arifin et al., 2012). Pemanfaatan lahan pekarangan dengan mengkombinasikan antara pohon, tanaman semusim, tanaman hias dan tanaman lainnya serta ternak yang dapat hidup bersama-sama, maka pekarangan telah memenuhi prinsip keberlanjutan secara ekologi dan sosial (Junaidah et al., 2016).

Lahan pekarangan yang dimiliki jika dimanfaatkan sebaik-baiknya, banyak keuntungan yang diperoleh seperti dapat mengurangi biaya belanja kebutuhan pangan terurama sayuran dan rempah serta kebutuhan sehari-hari mudah terpenuhi (Lais et al., 2017). Lebih lanjut Shrestha et al (2002) menyatakan bahwa tanaman di lahan pekarangan rumah tangga, sayuran dan buah-buahan sebagian besar ditanam secara organik sehingga menghasilkan makanan yang aman dan sehat untuk konsumsi rumah tangga.

Pemanfaatan pekarangan adalah sebagai pemanfaatan lahan secara tradisional disekitar tempat tinggal yang ditanami berbagai jenis tanaman oleh anggota rumah tangga dan produknya diperuntukkan komsumsi rumah tangga. Pekarangan adalah salah satu sumber penting makanan dan pasokan sebagian besar kebutuhan rumah tangga yaitu sayuran dan buah-buahan. Pekarangan di daerah perkotaan juga dimanfaatkan dalam berbagai bentuk dan ukuran yang berkontribusi pada pasokan sayuran dan buah-buahan setiap hari (Shrestha et al., 2002).

Sangatta sebagai Ibu Kota Kabupaten Kutai Timur, sebagian besar masyarakatnya kurang mendapatkan informasi tentang pemanfaatan pekarangan dan belum teridentifikasi, maka perlu dilakukan penelitian mengenai Identifikasi Pekarangan Untuk Menunjang Ketahanan Pangan Keluarga di Kecamatan Sangatta Utara Kabupaten Kutai Timur. Tujuan penelitian ini adalah mengidentifikasi komposisi, pola pemanfaatan, produksi, produktivitas dan potensi pemanfaatan lahan pekarangan masyarakat untuk mendukung ketahanan pangan keluarga di Kecamatan Sangatta Utara Kabupaten Kutai Timur. 


\section{Metode Penelitian}

\section{Waktu dan Tempat}

Penelitian dilaksanakan pada bulan April-Mei 2019 di Kabupaten Kutai Timur Kecamatan Sangatta Utara. Pemilihan lokasi didasarkan pertimbangan di Kecamatan Sangatta Utara bahwa masyarakat telah menerapkan pemanfaatan lahan pekarangan.

\section{Cara Kerja}

Penentuan lokasi penelitian dilakukan dengan metode secara sengaja (purposive sampling) berdasarkan kategori luas pekarangan. Metode yang digunakan adalah metode survei. Metode survei yang digunakan dibatasi pada pengertian survei sampel, dimana hanya dari populasi saja yang diambil dan dipergunakan untuk menentukan sifat serta ciri yang dikehendaki dari populasi (Nazir, 2005). Sampel bersal dari rumah tangga petani sebanyak 30 sampel secara sengaja (purposive sampling) dengan luas lahan pekarangan yang dikelompokan menjadi tiga strata yaitu strata 1 (0,5-1.0 ha), strata 2 (>1-1,5 ha) dan strata 3 (>1,5-2,0 ha).

Pengambilan sampel dilakukan terhadap 30 rumah tangga petani dengan observasi langsung di pekarangan yaitu dengan mendata pemanfaatan pekarangan dari 3 strata luas pekarangan yang meliputi: 1) Status kepemilkan lahan pekarangan, 2) Luas dan Persentase Lahan Pekarangan, 3) Struktur dan komposisi jenis vegetasi dan hewan di lahan pekarangan, 4) Struktur dan komposisi penyusun lahan pekarangan adalah jenis tanaman, ternak dan ikan yang dipilih sesuai keinginan keluarga petani untuk diusahakan atau ditanam dan dibudiayakan di lahan pekarangan, 5) Klasifikasi pengelolaan lahan pekarangan, 6) Produksi lahan pekarangan baik jenis tanaman, ternak dan ikan berdasarkan periode panen dalam setahun, yaitu setiap hasil panen dari jenis tanaman, ternak dan ikan yang diusahakan oleh keluarga petani di pekarangan dihitung berdasarkan frekuensi pemanenan dalam satu tahun. Hasil pendapatan lahan pekarangan dalam satu tahun dikonversi ke beras per bulan.

Sumber data yang dikumpulkan yaitu pengumpulan data primer yang dilakukan dengan cara observasi di lapangan dan diambil secara langsung pada obyek sasaran penelitian atau wawancara langsung dengan keluarga petani dengan menggunakan kuisioner (daftar pertanyaan) yang disusun secara teratur sesuai dengan tujuan penelitian dan pengumpulan data sekunder dengan mengumpulkan data-data dari literatur (studi pustaka), dokumentasi dan laporan dari instansi yang berkaitan dengan wilayah studi.

\section{Metode Pengolahan dan Analisis Data}

1. Status kepemilkan lahan pekarangan (SKP)

Status kepemilkan lahan pekarangan merupakan lahan milik sendiri dan bukan milik sendiri (Pengelola dan Jaga Lahan tanpa Sewa). Status kepemilikan lahan pekarangan 
dianalisis dengan menghitung jumlah sampel milik sendiri atau pengelola dibagi dengan jumlah sampel dengan rumus sebagai berikut:

$$
S K P=\frac{\Sigma S K P}{\Sigma \text { Sampel }} x 100 \%
$$

2. Luas dan Persentase Lahan Pekarangan (LPP)

Dianalisis dengan menghitung jumlah sampel yang memiliki luasan (strata 1, 2 dan 3) dibagi dengan jumlah sampel dengan rumus sebagai berikut:

$$
L P P=\frac{\Sigma L P P}{\Sigma \text { Sampel }} x 100 \%
$$

3. Struktur dan komposisi jenis vegetasi dan hewan di lahan pekarangan (SKJP)

Dianalisis dengan menghitung jumlah sampel yang memnfaatkan pekarangan berdasarkan struktur dan komposisi jenis vegetasi dan hewan di lahan pekarangan dibagi dengan jumlah sampel dengan rumus sebagai berikut:

$$
S K J P=\frac{\Sigma S K J P}{\Sigma \text { Sampel }} x 100 \%
$$

4. Struktur dan komposisi penyusun lahan pekarangan (SKPP)

Dianalisis dengan menghitung jumlah sampel yang memnfaatkan pekarangan berdasarkan struktur dan komposisi penyusun lahan pekarangan dibagi dengan jumlah sampel dengan rumus sebagai berikut:

$$
\text { SKPP }=\frac{\Sigma \text { SKPP }}{\Sigma \text { Sampel }} x 100 \%
$$

5. Klasifikasi pengelolaan lahan pekarangan (KPP)

Klasifikasi pengelolaan lahan pekarangan yaitu agrosilvikultur (tanaman tahunan dan pertanian), agrosilvopastura (tanaman tahunan, pertanian dan ternak), agrosilvofishery (tanaman tahunan, pertanian dan budidaya ikan), agrosilvopasturafishery (tanaman tahunan, pertanian, peternakan dan budidaya ikan). Dianalisis dengan menghitung jumlah sampel yang memnfaatkan pekarangan berdasarkan Klasifikasi pengelolaan lahan pekarangan dibagi dengan jumlah sampel dengan rumus sebagai berikut:

$$
K P P=\frac{\Sigma K P P}{\Sigma \text { Sampel }} x 100 \%
$$

6. Produktivitas

Produktivitas pekarangan keluarga petani (sampel) di Kecamatan Sangatta Utara dianalisis menggunakan rumus sebagai berikut:

$$
\text { Produktivitas }=\frac{\text { Jumlah Produksi }}{\text { Luas Lahan }} \frac{(\mathrm{kg})}{(\mathrm{ha})}
$$

7. Konversi Beras (KB)

Dianalisis dengan menghitung pendapatan lahan pekarangan dibagi dengan harga beras dengan rumus sebagai berikut:

$$
K B=\frac{\Sigma \text { Total Hasil Pekarangan }}{\text { Harga Beras }}
$$


Harga konversi hasil pekarangan menjadi harga beras adalah Rp. 12.000,. Harga ini berdasarkan harga bahan pangan di Pasar Induk Sangatta (BPS Kabupaten Kutai Timur, 2019).

8. Hasil pendapatan lahan pekarangan dikonversi ke beras (HPP).

Dianalisis dengan menghitung pendapatan lahan pekarangan dibagi dengan jumlah sampel dengan rumus sebagai berikut:

$$
H P P=\frac{\Sigma \text { Total Pendapatan Lahan Pekarangan }}{\Sigma \text { Sampel }} \times 100 \%
$$

9. Hasil pendapatan rata-rata komposisi lahan pekarangan dikonversi ke beras (HPP Ratarata). Dianalisis dengan menghitung pendapatan rata-rata lahan pekarangan dalam satu tahun dibagi dengan harga beras dibagi jumlah sampel dengan rumus sebagai berikut:

$$
H P P_{\text {Rata-rata }}=\frac{\Sigma \text { Total Rata-rata Pendapatan Lahan Pekarangan }}{\Sigma \text { Sampel }} \times 100 \%
$$

\section{Analisis Regresi}

\section{Produktivitas Komposisi Lahan Pekarangan}

Analisis ini bertujuan untuk mengetahui seberapa besar pengaruh variabel bebas tanaman perkebunan dan kehutanan $\left(X_{1}\right)$, palawija $\left(X_{2}\right)$, tanaman buah-buahan $\left(X_{3}\right)$, tanaman sayuran $\left(X_{4}\right)$, tanaman rempah dan obat $\left(X_{5}\right)$, hewan ternak dan unggas $\left(X_{6}\right)$, dan budidaya ikan $\left(X_{7}\right)$ terhadap produktivitas pekarangan berdasarkan periode panen untuk menunjang ketahanan pangan rumah tangga di Kecamatan Sangatta Utara Kabupaten Kutai Timur (Y).

Regresi digunakan untuk mengukur besarnya pengaruh variabel bebas terhadap variabel tidak bebas dan memprediksi variabel tidak bebas dengan menggunakan variabel bebas. Analisis regresi yang digunakan dalam penelitian ini adalah regresi linier berganda. Adapun persamaan regresi linear berganda menurut Gaspersz (1995) dapat dirumuskan sebagai berikut:

$$
Y=a+b_{1} X_{1}+b_{2} X_{2}+b_{3} X_{3}+\ldots b_{n} X_{3}+e
$$

Keterangan: $\hat{Y}$ = Produktivitas komposisi lahan pekarangan

$\mathrm{X}_{1}=$ Tanaman perkebunan dan kehutanan

$\mathrm{X}_{2}=$ Tanaman palawija

$\mathrm{X}_{3}=$ Tanaman buah-buahan

$\mathrm{X}_{4}=$ Tanaman sayuran

$\mathrm{X}_{5}=$ Tanaman obat dan rempah

$X_{6}=$ Hewan ternak dan unggas

$\mathrm{X}_{7}$ = Budidaya ikan

$\mathrm{a}=$ Intersep

$b_{1}, b_{2} \ldots \ldots b_{n}=$ Koefisien parameter penduga

$\mathrm{e}=$ standar error 


\section{Hasil dan Pembahasan}

Kecamatan Sangatta Utara merupakan kecamatan di wilayah kabupaten Kutai Timur yang memiliki jumlah penduduk terbanyak, dibandingkan dengan kecamatan yang lain. Hal ini disebabkan karena kecamatan Sangatta Utara adalah pusat pemerintahan dan perdagangan di Kutai Timur. Kecamatan Sangatta Utara saat ini memiliki jumlah penduduk kurang lebih 90.152 jiwa, yang kegiatan masyarakatnya terdiri dari berbagai sektor pertambangan, pertanian, perdagangan, PNS, Nelayan, Pengrajin, Buruh, Pensiunan dan lain sebagainya (BPS Kabupaten Kutai Timur, 2019).

\section{Luas Lahan Pekarangan}

Lahan yang menjadi sampel penelitian merupakan lahan hak milik sendiri dan lahan bukan milik sendiri. Lahan yang bukan milik sendiri merupakan lahan yang dipercayakan oleh pemilik lahan kepada penjaga lahan untuk diolah sekaligus untuk menjaga lahan tersebut agar tidak ditumbuhi gulma dan rumput liar lainnya. Lahan pekarangan ini diperoleh dari pembagian lahan untuk para kelompok tani pada tahun 1997-1999 dengan luas masing-masing $2.000 \mathrm{~m}^{2}$ per kepala keluarga.

Tabel 1 menunjukkan bahwa 53,3\% lahan pekarangan yang diolah oleh petani sampel bukan merupakan lahan milik sendiri melainkan lahan yang dijaga sekaligus diolah untuk ditanami berbagai jenis tanaman pertanian yang hasilnya untuk petani pengelola tersebut dan 46,7\% merupakan lahan milik sendiri dan dioalah sendiri.

Tabel 1. Status kepemilikan lahan pekarangan

\begin{tabular}{cccc}
\hline No. & Status Kepemilikan & Jumlah (Orang) & Persentase (\%) \\
\hline 1 & Milik sendiri & 14 & $46,7 \%$ \\
2 & Sewa & 0 & $0,0 \%$ \\
3 & Pengelola dan jaga lahan & 16 & $53,3 \%$ \\
\hline \multicolumn{2}{c}{ Jumlah } & 30 Orang & $100,0 \%$ \\
\hline
\end{tabular}

Dengan adanya sistem bagi waris (heritage system) dan sistem jual beli lahan, luas lahan pekarangan menjadi bervariasi antara $500-2000 \mathrm{~m}^{2}$ (Tabel 2). Luas pekarangan antara 1.000-2.500 $\mathrm{m}^{2}$ termasuk dalam klasifikasi luasan lahan pekarangan yang sangat besar yaitu lebih dari $1000 \mathrm{~m}^{2}$. Hal ini sesuai dengan Arifin (1998) yang membagi luas tapak pekarangan menjadi 4: (A) kecil, kurang dari $200 \mathrm{~m}^{2}$, (B) sedang, 200-500 m², (C) besar, 500-1000 $\mathrm{m}^{2}$, dan (D) sangat besar, lebih dari $1.000 \mathrm{~m}^{2}$.

Sistem bagi waris dan fragmentasi pada kelompok masyarakat tertentu memicu terjadinya perubahan dalam pekarangan. Lahan pekarangan dapat diwariskan, dibagi dan juga dipindah-tangankan karena merupakan wujud barang. Semua barang milik orang tua, termasuk rumah dan pekarangan dalam masyarakat tertentu apabila kedua orang tuanya meninggal akan diwariskan kepada anak-anaknya. Ukuran luas pekarangan semakin hari semakin sempit dan berdampak pada struktur serta fungsi pekarangan aibat dari sistem pewarisan tersebut (Arifin, 1998). 
Tabel 2. Luas dan presentase lahan pekarangan

\begin{tabular}{cccc}
\hline No. & Luas Lahan $\left.\mathbf{( m}^{\mathbf{2}}\right)$ & Jumlah (Orang) & Persentase (\%) \\
\hline 1 & $5.000-10.000$ & 13 & $43,3 \%$ \\
2 & $10.001-15.000$ & 5 & $16,7 \%$ \\
3 & $15.001-20.000$ & 12 & $40,0 \%$ \\
\hline & Jumlah & 30 Orang & $100,0 \%$ \\
\hline
\end{tabular}

\section{Struktur dan Komposisi Lahan Pekarangan}

Struktur lahan pekarangan di lokasi penelitian terdiri atas tanaman dan tumbuhan (vegetasi), hewan (ternak dan ikan) atau elemen lunak; dan elemen keras yaitu unsur sarana dan prasarana serta fasilitas, yaitu kandang ternak, sumur tanah, kolam ikan, pagar, jalan setapak, tiang jemuran dan lain-lain.

Tabel 3 menunjukkan bahwa lahan pekarangan di lokasi penelitian didominasi oleh struktur vegetasi dan hewan dengan jenis tanaman dan hewan yang beragam. Jenis tanaman yang umumnya terdapat di lokasi penelitian yaitu tanaman tahunan $83 \%$, tanaman semusim 96\%, tanaman rempah dan toga 40\%, sedangkan jenis hewan yaitu ternak $40 \%$, dan ikan 20\%. Mugnisjah et al., (2009) menyatakan bahwa struktur pensyusun lahan pekarangan terdiri atas, berbagai jenis tanaman, hewan, kolam ikan, jalan setapak, lampu taman, pagar, perkerasan dari kerikil, kandang, dan jemuran.

Tabel 3. Struktur dan komposisi jenis vegetasi dan hewan di lahan pekarangan

\begin{tabular}{llcc}
\hline No. & Struktur Lahan Pekarangan & Jumlah & Persentase (\%) \\
\hline & Tanaman & & \\
\hline 1 & Tanaman Tahunan & 25 & $83,3 \%$ \\
2 & Tanaman Semusim & 29 & $96,7 \%$ \\
3 & Tanaman Rempah/Toga & 12 & $40,0 \%$ \\
\hline & Ternak dan Ikan & & \\
\hline 4 & Ternak & 12 & $40,0 \%$ \\
5 & lkan & 6 & $20,0 \%$ \\
\hline
\end{tabular}

Komposisi tanaman dan ternak dilahan pekarangan umumnya berupa campuran (multi komoditas). Berbagai macam komoditas baik berupa tanaman tahunan maupun tanaman semusim yang ditanam oleh petani. Petani juga menanam berbagai jenis komoditas tanaman pangan, holtikultura, perkebunan, dan memelihara berbagai jenis ternak maupun ikan. Jenis komposisi komoditas yang diusahakan berdasarkan pemilihan dan mempertimbangkan tujuan utama budidaya apakah untuk sekedar memenuhi kebutuhan pangan sehari-hari, komersial, konservasi, dan sebagainya.

Komposisi tanaman dan hewan penyusun lahan pekarangan seperti pada Tabel 4. Komoditi tanaman buah-buahan yaitu sekitar $90 \%$, tanaman sayuran $66,7 \%$, palawija $50 \%$, ternak dan unggas $40 \%$, tanaman perkebunan dan kehutanan $30 \%$, dan budidaya ikan sebesar $20 \%$. 
Tabel 4. Struktur dan komposisi penyusun lahan pekarangan

\begin{tabular}{clcc}
\hline No. & Jenis Komposisi & Jumlah & Persentase (\%) \\
\hline 1 & Tanaman perkebunan dan kehutanan (tegakan) & 9 & $30,0 \%$ \\
2 & Palawjia & 15 & $50,0 \%$ \\
3 & Tanaman buah-buahan & 27 & $90,0 \%$ \\
4 & Tanaman sayuran & 20 & $66,7 \%$ \\
5 & Tanaman rempah dan obat & 12 & $40,0 \%$ \\
6 & Hewan ternak dan ungags & 14 & $46,7 \%$ \\
7 & Budidaya ikan & 6 & $20,0 \%$ \\
\hline
\end{tabular}

Tanaman buah-buahan terdapat hampir semua di lahan lokasi penelitian, tanaman jenis ini banyak dibudidaya karena selain berfungsi sebagai pelindung dan memiliki nilai komersil yang sangat besar, tanaman ini juga mudah tumbuh di setiap lahan pekarangan lokasi penelitian. Dari 30 sampel, 27 petani mempunyai tanaman buah-buahan di lahan pekarangan mereka. Tanaman sayuran selain untuk pemenuhan kebutuhan pangan sehari-hari juga untuk komersil, tanaman jenis ini banyak ditanam di lahan pekarangan karena mudah tumbuh, perawatan yang tidak susah dan umur panen yang relatif pendek sehingga sangat membantu dalam ekonomi sehari-hari petani.

Unggas yang ada di lahan pekarangan umumnya dilepas secara bebas, jenis ini hanya dipelihara secara non intensif. Hewan peliharaan ini dilepas bebas di lahan pekarangan sehingga bebas mencari makanan sendiri, namun dibuatkan khusus kandang hanya untuk tempat berlindung pada saat hujan dan malam hari.

\section{Sistem Pengelolaan Lahan Pekarangan}

Sistem pengelolaan pekarangan di lokasi penelitian memiliki fungsi yang spesifik sebagai agroforestry kompleks. Pekarangan merupakan salah satu bentuk sistem agroforestri yang kompleks (Foresta et al., 2000). Hal ini dapat dilihat dari kombinasi komponen penyusun pekarangan tersebut. Klasifikasi pengelolaan pekarangan di lokasi penelitian dapat dilihat pada Tabel 5 .

Tabel 5. Klasifikasi pengelolaan lahan pekarangan

\begin{tabular}{clcc}
\hline No. & Klasifikasi Lahan Pekarangan & Jumlah (Orang) & Persentase (\%) \\
\hline 1 & Agrosilvikultur & 9 & $30,0 \%$ \\
2 & Agrosilvopastura & 12 & $40,0 \%$ \\
3 & Agrosilvofishery & 6 & $20,0 \%$ \\
4 & Agrosilvopasturafishery & 5 & $16,7 \%$ \\
\hline
\end{tabular}

Berdasarkan Tabel 5, pekarangan yang dikelola sebagai subsistem agrosilvikultur sebanyak 9 pekarangan (30\%), agrosilvopastura sebanyak 12 pekarangan (40\%), agrosilvofishery sebanyak 6 pekarangan (20\%), agrosilvopasturafishery sebanyak 5 pekarangan (16\%). Pekarangan yang terdiri dari berbagai spesies dan dikelola secara berkelanjutan sehingga strukturnya menjadi kompleks. 


\section{Ketahanan Pangan Rumah Tangga}

\section{Produktivitas Lahan Pekarangan}

Potensi pekarangan yang ada di lokasi penelitian cukup luas untuk dikembangkan dalam memproduksi aneka ragam bahan pangan yang bergizi untuk keluarga. Melihat potensi lahan pekarangan yang ada, maka untuk memenuhi kebutuhan keluarga, tanaman perkebunan, sayuran, buah-buahan, obat-obatan, beternak dan memelihara ikan pada umunya dapat dilakukan pada lahan pekarangan.

Lahan pekarangan yang dimanfaatkan dapat mengahasilkan berbagai pangan yang bergizi bagi keluarga dan menjamin ketahanan pangan secara utuh setiap rumah tangga serta memberi langka komparatif dan kompetitif secara berkesinambungan. Produktivitas lahan pekarangan pada sampel lokasi penelitian seperti pada Tabel 6.

Tabel 6. Pendapatan per bulan lahan pekarangan (konversi ke satuan $\mathrm{kg}$ beras)

\begin{tabular}{clcc}
\hline No. & Pendapatan $\mathbf{( k g )}$ Beras & Jumlah & Persentase (\%) \\
\hline 1 & $<49.99$ & 0 & $0,00 \%$ \\
2 & $50.00-99.99$ & 0 & $0,00 \%$ \\
3 & $100-149.99$ & 1 & $3,33 \%$ \\
4 & $150-199.99$ & 11 & $36,67 \%$ \\
5 & $200-249.99$ & 13 & $43,33 \%$ \\
6 & $>250$ & 5 & $16,67 \%$ \\
\hline \multicolumn{2}{c}{ Jumlah } & 30 & $100.00 \%$ \\
\hline
\end{tabular}

Tabel 6 menunjukkan bahwa pendapatan dari lahan pekarangan dengan jumlah 13 sampel (43,33\%) mempunyai pendapatan dari lahan pekarangan diantara 200-249,999 kg beras, 11 sampel (36,67\%) berpendapatan diantara 150-199,999 kg beras, 5 sampel $(16,67 \%)$ berpendapatan diatas $250 \mathrm{~kg}$ beras bulan, 1 sampel $(3,33 \%)$ berpendapatan diantara 100-149,999 kg beras.

Yulida (2012) bahwa rata-rata pendapatan lahan pekarangan lebih dari Rp. 900.000,- atau setara dengan $75 \mathrm{~kg}$ beras bulan-1 termasuk dalam golongan tinggi. Pendapatan rumah tangga dari lahan pekarangan di lokasi penelitian dikategorikan tinggi

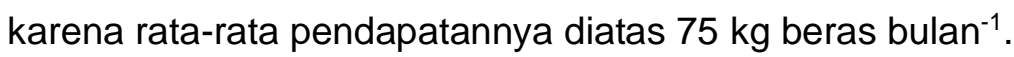

\section{Produktivitas Komposisi Lahan Pekarangan Terhadap Pendapatan Lahan Pekarangan Rumah Tangga}

Pendapatan merupakan selisih antara biaya produksi dan penerimaan, pendapatan yang diterima oleh responden. Pemanfaatan lahan pekarangan berdasarkan komposisi tanaman yang ada di lahan pekarangan pada Tabel 8. Dilihat dari kontribusi produktivitas yang telah diberikan komposisi pemanfaatan lahan pekarangan, hasil penelitian menujukkan rata-rata produktivitas yang telah disumbangkan komposisi lahan pekarangan terhadap pendapatan rumah tangga petani adalah sebagai berikut; tanaman perkebunan dan kehutanan (tegakan) sebesar $6 \mathrm{~kg}$ bulan $^{-1}$, palawija sebesar 9,04 $\mathrm{kg}_{\text {bulan }}^{-1}$, tanaman buah-buahan sebesar $224 \mathrm{~kg}_{\text {bulan }}^{-1}$, tanaman sayuran sebesar $539 \mathrm{~kg}^{\text {bulan }}{ }^{-1}$, tanaman 
rempah dan obat sebesar $3,02 \mathrm{~kg}$ bulan $^{-1}$, hewan ternak dan unggas sebesar 19,87 $\mathrm{kg}$ bulan $^{-1}$, dan budidaya ikan sebesar 7,28 kg bulan ${ }^{-1}$.

Tabel 7. Pendapatan rata-rata komposisi lahan pekarangan

\begin{tabular}{clc}
\hline No. & Jenis Komposisi & Rata-rata Pendapatan (kg Beras) \\
\hline 1 & Tanaman perkebunan dan kehutanan (tegakan) & 6,00 \\
2 & Palawija & 9,04 \\
3 & Tanaman buah-buahan & 224,00 \\
4 & Tanaman sayuran & 539,00 \\
5 & Tanaman rempah dan obat & 3,02 \\
6 & Hewan ternak dan ungags & 19,87 \\
7 & Budidaya ikan & 7,28 \\
\hline
\end{tabular}

Pemanfaatan lahan pekarangan sebagai usahatani dirasakan petani berperan cukup penting dan memberi manfaat baik secara ekonomi maupun sosial dengan bertambahnya pendapatan rumah tangga walaupun rata-rata produktivitas tidak besar. Selain berfungsi sebagai sumber ekonomi, pemanfaatan lahan pekarangan juga memberi sumbangan sosial di masyarakat. Petani saling bertukar informasi tentang usahatani yang mereka lakukan dan membagi hasil pekarangannya saat panen (Yulida, 2012).

\section{Hasil Regresi}

Berdasarkan hasil uji parsial menunjukkan bahwa persamaan regresi untuk variabel dependen dan independen yaitu tanaman perkebunan dan kehutanan (tegakan) $\left(X_{1}\right)$, tanaman palawija $\left(X_{2}\right)$, tanaman buah-buahan $\left(X_{3}\right)$, tanaman sayuran $\left(X_{4}\right)$, tanaman rempah dan obat $\left(X_{5}\right)$, hewan ternak dan unggas $\left(X_{6}\right)$, dan budidaya ikan $\left(X_{7}\right)$ terhadap produktivitas pekarangan berdasarkan periode panen untuk menunjang ketahanan pangan rumah tangga di Kecamatan Sangatta Utara Kabupaten Kutai Timur (Y) diperoleh persamaan regresi sebagai berikut:

$$
\begin{gathered}
Y=-143,628-1,066\left(X_{1}\right)+1,295\left(X_{2}\right)+0,436\left(X_{3}\right)+0,572\left(X_{4}\right) \\
+4,659\left(X_{5}\right)+0,981\left(X_{6}\right)+4,339\left(X_{7}\right) .
\end{gathered}
$$

Berdasarkan persamaan di atas, dapat diterjemahkan bahwa dengan asumsi bahwa produktivitas tidak berubah maka, setiap kenaikan $1 \mathrm{~kg}$ (setara harga $1 \mathrm{~kg}$ beras) hasil tanaman perkebunan dan kehutanan pada lahan pekarangan maka akan menurunkan $1,066 \mathrm{~kg}$ (setara harga $1 \mathrm{~kg}$ beras) produktivitas lahan pekarangan, setiap kenaikan $1 \mathrm{~kg}$ (setara harga $1 \mathrm{~kg}$ beras) hasil tanaman palawija pada lahan pekarangan maka akan menaikkan $1,295 \mathrm{~kg}$ (setara harga $1 \mathrm{~kg}$ beras) produktivitas lahan pekarangan, setiap kenaikan $1 \mathrm{~kg}$ (setara harga $1 \mathrm{~kg}$ beras) hasil tanaman buah-buahan pada lahan pekarangan maka akan menaikkan $0,436 \mathrm{~kg}$ (setara harga $1 \mathrm{~kg}$ beras) produktivitas lahan pekarangan, setiap kenaikan $1 \mathrm{~kg}$ (setara harga $1 \mathrm{~kg}$ beras) hasil tanaman sayuran pada lahan pekarangan maka akan menaikkan $0,572 \mathrm{~kg}$ (setara harga $1 \mathrm{~kg}$ beras) produktivitas lahan pekarangan. 
Demikian halnya pada setiap kenaikan $1 \mathrm{~kg}$ (setara harga $1 \mathrm{~kg}$ beras) hasil tanaman rempah dan obat pada lahan pekarangan maka akan menaikkan 4,659 kg (setara harga 1 $\mathrm{kg}$ beras) produktivitas lahan pekarangan, setiap kenaikan $1 \mathrm{~kg}$ (setara harga $1 \mathrm{~kg}$ beras) hasil hewan ternak dan unggas pada lahan pekarangan maka akan menaikkan 0,981 kg (setara harga $1 \mathrm{~kg}$ beras) produktivitas lahan pekarangan, dan setiap kenaikan $1 \mathrm{~kg}$ (setara harga $1 \mathrm{~kg}$ beras) hasil budidaya ikan pada lahan pekarangan maka akan menaikkan 4,339 $\mathrm{kg}$ (setara harga $1 \mathrm{~kg}$ beras) produktivitas lahan pekarangan.

\section{Kesimpulan}

Tingkat produksi lahan pekarangan rumah tangga menunjukkan pendapatan dari lahan pekarangan rumah tangga tinggi, rata-rata pendapatan lahan pekarangan diatas 75 $\mathrm{kg}$ beras bulan-1 dengan produktivitas sebanyak 13 lahan pekarangan $(43,33 \%)$ dengan produksi antara 200-249,999 kg beras bulan-1, 11 lahan pekarangan $(36,67 \%)$ dengan produksi antara 150-199,999 $\mathrm{kg}$ beras bulan ${ }^{-1}, 5$ lahan pekarangan (16,67\%) dengan produksi diatas $250 \mathrm{~kg}$ beras bulan ${ }^{-1}, 1$ lahan pekarangan (3,33\%) dengan produksi antara $100-149,999 \mathrm{~kg}$ beras bulan ${ }^{-1}$.

Pemanfaatan lahan pekarangan memberikan kontribusi yang cukup besar dalam peningkatan ekonomi rumah tangga dan menunjang ketahanan pangan keluarga di Kecamatan Sangatta Utara, produktivitas rata-rata komposisi lahan pekarangan terhadap pendapatan lahan pekarangan rumah tangga adalah tanaman perkebunan dan kehutanan (tegakan) sebesar $6 \mathrm{~kg}$ bulan-1 $^{-1}$, palawija sebesar 9,04 kg bulan ${ }^{-1}$, tanaman buah-buahan sebesar $224 \mathrm{~kg}$ bulan $^{-1}$, tanaman sayuran sebesar $539 \mathrm{~kg}$ bulan $^{-1}$, tanaman rempah dan obat sebesar 3,02 kg bulan ${ }^{-1}$, hewan ternak dan unggas sebesar 19,87 $\mathrm{kg} \mathrm{bulan}^{-1}$, dan budidaya ikan sebesar 7,28 $\mathrm{kg}_{\text {bulan }}{ }^{-1}$.

\section{Daftar Pustaka}

Arifin, H. S. (1998). Studi on the Vegetation Structure of Pekarangan and its Changes in West Java, Indonesia. Disertation. Graduate School of Natural Science and Technology. Okayama University, Japan.

Arifin, H. S., Munandar, A., Schultink, G., \& Kaswanto, R. L. (2012). The Role And Impacts Of Small-Scale, Homestead Agro-Forestry Systems ("Pekarangan") On Household Prosperity: An Analysis Of AgroEcological Zones Of Java, Indonesia. International Journal of AgriScience, 2(10), 896-914.

BKP Kabupaten Kutai Timur. (2017). Laporan Kinerja Instansi Pemerintah (LKj-IP) Tahun Anggaran 2016. Sangatta: DKP Kabupaten Kutai Timur.

BKP Kementan. (2019). Indeks Ketahanan Pangan Indonesia 2019. In Food Security Bureau, Republic of Indonesia. Jakarta: BKP Kementerian Pertanian. 
BPS Kabupaten Kutai Timur. (2019). Kecamatan Sangatta Utara Dalam Angka. Sangatta: BPS Kabupaten Kutai Timur.

Cholida, F. (2016). Analisis Ketahanan Pangan Rumah Tangga di Kabupaten Timor Tengah Selatan Provinsi Nusa Tenggara Timur dan Hubungannya Dengan Status Gizi Balita, Tesis. Institut Pertanian Bogor, Bogor.

FAO. (2006). Food security.Http:/Www.Fao.Org/Filedmin/Templates/Faoitaly/Documents/ Pdf_Food_Security_Cocept_Note.Pdf, Diakses Tanggal 13 Maret 2019, (2), 1-4. https://doi.org/10.1016/0306-9192(76)90001-4

FAO. (2009). Declaration of the World Summit on Food Security, Rome 16-18 November 2009. Rome.

Fawole, W. O., \& Ozkan, B. (2017). The Systemic Review of Food Security Assessment Indicators: Understanding the Strenghts and Weaknesses of the Indicators. Journal of Agriculture and Rural Research, 1(1), 24-31.

Foresta, H. de, Kusworo, A., Michon, G., \& Djatmiko, W. (2000). Ketika Kebun Berupa Hutan - Agroforest Khas Indonesia - Sumbangan Masyarakat Bagi Pembangunan Berkelanjutan. Bogor: ICRAF.

Gaspersz, V. (1995). Teknik Analisis Dalam Percobaan (Edisi Pert). Bogor: Tarsito.

Junaidah, Suryanto, P., \& Budiadi. (2017). Komposisi Jenis Dan Fungsi Pekarangan (Studi kasus desa Giripurwo, Kecamatan Girimulyo, di Yogyakarta). Jurnal Hutan Tropis, 4(1), 77-84. https://doi.org/10.20527/jht.v4i1.2884

Lais, H., Pangemanan, P. A., \& Jocom, S. G. (2018). Pemanfaatan Pekarangan Keluarga Petani Di Desa Para-Lele, Kecamatan Tatoareng, Kabupaten Kepulauan Sangihe. Agri-Sosioekonomi, 13(3A), 373-384. doi: 10.35791/agrsosek.13.3a.2017.18654

Leroy, J. L., Ruel, M., Frongillo, E. A., Harris, J., \& Ballard, T. J. (2015). Measuring the Food Access Dimension of Food Security: A Critical Measuring the Food Access Dimension of Food Security : A Critical Review and Mapping of Indicators. Food and Nutrition Bulletin, 36(2), 167-195. https://doi.org/10.1177/0379572115587274

Mugnisjah, W. Q., Nurfaida, \& Pujowati, P. (2009). Evaluasi Pekarangan sebagai Sistem Agroforestri dan Permakultura. In A. Bintoro, Budiadi, B. Sulistiyawan, C. Wulandari, L. Sundawati, N. Wijayanto, \& R. Qumiati (Eds.), Prosiding Penelitian-pcnclitian Agroforestri di Indonesia Tahun 2006-2009 (pp. 189-206). Bandar Lampung: Lembaga Penelitian Universitas Lampung.

Nazir, M. (2005). Metode Penelitian. Bogor: Ghalia Indonesia.

Nurwati, N., Lidar, S., \& Mufti. (2015). Model Pemberdayaan Pekarangan Di Kecamatan Rumbai Pesisir Kota Pekanbaru. Jurnal Agribisnis, 17(1), 1-9. 
Shrestha, P., Gautam, R., Rana, R. B., \& Sthapit, B. (2002). Home gardens in Nepal: status and scope for research and development. In J. W. Watson \& P. B. Eyzaguirre (Eds.), Homegardens and in situ Conservation of Plant Genetic Resources in Farming Systems. Proceedings of the Second International Home Gardens Workshop, 17-19 July 2001, Witzen-hausen, Federal Republic of Germany. (Vol. 39, pp. 110-110). https://doi.org/10.1017/S0014479702251054

UU RI Nomor 18 Tahun 2012. Undang-Undang Republik Indonesia Nomor 18 Tahun 2012 Tentang Pangan. Pub. L. No. 18 (2012).

Yulida, R. (2012). Kontribusi Usahatani Lahan Pekarangan Terhadap Ekonomi Rumah Tangga Petani Di Kecamatan Kerinci Kabupaten Pelalawan. Indonesian Journal of Agricultural Economics (IJAE), 3(2), 135-154. 